\title{
Alternaria Late Blight (Alternaria alternata) Resistance in Pistachio (Pistacia vera) and Selection of Resistant Genotypes
}

\author{
Chih-Cheng T. Chao ${ }^{1}$ \\ Department of Botany and Plant Sciences, University of California-Riverside, Riverside, CA 92521 \\ Dan E. Parfitt ${ }^{2}$ \\ Department of Pomology, University of California-Davis, Davis, CA 95616 \\ Themis J. Michailides ${ }^{3}$ \\ Department of Plant Pathology, University of California-Davis, Kearney Agricultural Center, Parlier, \\ CA 93648
}

AdDITIONAL INDEX woRDs. disease resistance, genetics, half-sib analysis, inheritance, heritability, nut tree breeding

\begin{abstract}
Pistachio (Pistacia vera L.) progeny were evaluated at two locations in California for resistance to alternaria late blight caused by Alternaria alternata (Fries) Keissler in 1995 and 1997. Large differences in alternaria late blight infection among seedlings were observed. Narrow sense heritabilities based on half-sib analysis of 20 open pollinated families were 0.48 and 0.11 at Kearney Agricultural Center in 1995 and 1997, respectively, and 0.56 and 0.54 at the Wolfskill Experimental Orchard near Davis in 1995 and 1997, respectively. Differences among families to alternaria late blight infection were highly significant and associated with the female parents. Fifty-eight highly resistant seedlings were identified for future cultivar selection efforts.
\end{abstract}

Pistachio (Pistacia vera) is an important tree nut crop in California as well as Europe and Asia. Total acreage of bearing pistachio in California has increased from 11,214 ha in 1977 to 33,655 ha in 1998 (California Pistachio Commission, 1999). Pistachio is diploid, dioecious, and wind pollinated. With the increasing production of pistachio in California, new pest problems are developing.

The California pistachio industry is based on a single female cultivar Kerman and a single male cultivar Peters. As a result, the pistachio crop has a high level of genetic uniformity and is vulnerable to new pests. One of the most severe diseases is alternaria late blight, caused by Alternaria alternata (Michailides et al., 1994, 1995). The pathogen infects both leaves and fruit, causes early defoliation, reduces yield, and stains nut shells (Michailides et al., 1996). The major impacts for growers are reduction in yield due to defoliation and rejection of nuts by processors due to cosmetic defects. Losses due to alternaria late blight can be significant in the northern and central California growing areas during wet years. Irrigation management and the use of fungicides can reduce the damage (Michailides et al., 1991, 1996, and 1997). However, application of fungicides is not highly effective, is costly, and has become more difficult due to environmental concerns. The most cost-effective and long-term disease management is to develop resistant cultivars. Before this study, there was no reported source of

Received for publication 3 May, 2000. Accepted for publication 5 Mar. 2001. This project was supported by a grant from the California Pistachio Commission. The authors also acknowledge assistance of L. Ferguson and F. Swanson for plot maintenance at Kearney Agricultural Center, and A. Bonin for similar services at Woflskill Experimental Orchard. This research used materials generated as part of a pistachio genetics and improvement program with cooperators D.E. Parfitt, C.T. Chao, L. Ferguson, C. Kallsen, and J. Maranto. The cost of publishing this paper was defrayed in part by the payment of page charges. Under postal regulations, this paper therefore must be hereby be marked advertisement solely to indicate this fact.

${ }^{1}$ Assistant cooperative extension specialist and assistant horticulturist; corresponding author: e-mail: ctchao@ citrus.ucr.edu.

${ }^{2}$ Pomologist.

${ }^{3}$ Plant pathologist. resistance in pistachio to alternaria late blight.

In 1995 and 1997, alternaria late blight occurred naturally at two test sites of an ongoing pistachio breeding program and offered unique opportunities to evaluate infection in the breeding population (Parfitt et al., 1998). Thus, field evaluations were conducted to determine if there is a genetic basis for resistance and to select resistant germplasm.

\section{Materials and Methods}

BREeding Population and Field eVAluation. The California pistachio cultivar improvement program began in 1989 with production of over 7,300 P. vera seedlings. Seedlings were planted in a randomized complete block design at three locations in California, each location with two replicated blocks: the University of Califor-

Table 1. ANOVA mean squares for all pistachio seedlings evaluated at KAC and WEO for alternaria late blight resistance in 1995 and 1997.

\begin{tabular}{|c|c|c|c|}
\hline Source & df & 1995 & 1997 \\
\hline Location & 1 & $17.67^{* *}$ & $258.71^{* *}$ \\
\hline Block & 1 & $1.57^{* *}$ & 0.02 \\
\hline $\mathrm{Sex}^{\mathrm{z}}$ & 2 & 0.04 & 0.04 \\
\hline Female $^{y}$ & 27 & $0.16^{*}$ & $0.13^{*}$ \\
\hline Male $^{\mathrm{x}}$ & 36 & $0.10^{* * *}$ & $0.09^{*}$ \\
\hline Sex $\times$ female $^{\mathrm{w}}$ & 52 & $0.09^{* *}$ & 0.58 \\
\hline Sex $\times$ male $^{\mathrm{w}}$ & 62 & 0.05 & 0.58 \\
\hline Female $\times$ male $^{v}$ & 85 & 0.07 & $0.06^{*}$ \\
\hline Error & 4038 & 0.06 & 0.05 \\
\hline
\end{tabular}

${ }^{\mathrm{z}} \mathrm{Sex}=$ effect of progeny on disease rating.

${ }^{y}$ Female $=$ effect of different female parents on disease rating.

${ }^{\mathrm{x}}$ Male $=$ effect of different male parents on disease rating.

${ }^{\mathrm{w}} \mathrm{S} \times \mathrm{F}$ or $\mathrm{S} \times \mathrm{M}=$ effect of interaction of sex of the seedling and either female or male parents.

${ }^{v}$ Female $\times$ male $=$ effect of female parents by male parents on disease rating.

*** Significant at $P=0.05$ or 0.01 , respectively. 
Table 2. ANOVA and heritability estimates for alternaria late blight resistance of pistacho progeny from open pollinated families in 1995 and 1997 at $\mathrm{KAC}$ and WEO.

\begin{tabular}{|c|c|c|c|c|c|c|c|c|}
\hline \multirow[b]{2}{*}{ Source } & \multicolumn{4}{|c|}{ KAC } & \multicolumn{4}{|c|}{ WEO } \\
\hline & df & Expected mean squares & 1995 & 1997 & df & Expected mean squares & 1995 & 1997 \\
\hline$\overline{\text { Block }}$ & 1 & $\delta^{2} \mathrm{e}+209.61 \delta^{2} \mathrm{~B}$ & $0.64^{*}$ & 0.07 & 1 & $\delta^{2} \mathrm{e}+481.56 \delta^{2} \mathrm{~B}$ & $0.35^{* *}$ & 0.04 \\
\hline Female & 19 & $\delta^{2} \mathrm{e}+21.09 \delta^{2} \mathrm{~F}$ & $0.39^{* *}$ & 0.11 & 19 & $\delta^{2} \mathrm{e}+47.234 \delta^{2} \mathrm{~F}$ & $0.32^{* *}$ & $0.19^{* *}$ \\
\hline Error & 408 & $\delta^{2} \mathrm{e}$ & 0.10 & 0.07 & 947 & $\delta^{2} \mathrm{e}$ & 0.04 & 0.02 \\
\hline$h^{2}$ estimate & & & 0.48 & 0.11 & & & 0.56 & 0.54 \\
\hline $\operatorname{SE}\left(h^{2}\right)$ & & & \pm 0.19 & \pm 0.10 & & & \pm 0.18 & \pm 0.17 \\
\hline
\end{tabular}

${ }^{* * * *}$ Significant at $P=0.05$ or 0.01 , respectively.

nia-Davis, Department of Pomology, Wolfskill Experimental Orchard at Winters (WEO), University of California, Kearney Agricultural Center at Parlier (KAC), and a commercial plot $30 \mathrm{~km}$ north of Bakersfield, provided by Paramount Farming Company. Seedlings at the Bakersfield location were not evaluated for alternaria late blight because of very little disease incidence at this location.

The KAC plot was flood irrigated and the WEO plot was irrigated with low trajectory angle sprinklers. About $80 \mathrm{~cm}$ of water was applied during the summers. The KAC site was often quite humid in the early morning with observable dew on the leaves while the WEO site was less humid. In 1995, atypical summer rains provided additional humidity at both locations. A high level of alternaria late blight developed at KAC, but less disease developed at WEO. Alternaria late blight developed in 1997 at KAC in response to favorable environmental stimuli. Some symptoms were also observed at WEO. Data were not collected in 1996 when conditions were unfavorable for disease development.

Disease severity was rated on a scale of 0 to 4 based on the level of whole tree foliar symptoms: $0=$ no lesions observed, $1=$ small necrotic areas on up to $30 \%$ of the leaves but no defoliation, $2=$ small necrotic areas to coalescing lesions on $50 \%$ of the leaves and some defoliation on the lower or upper branches, $3=$ large brown coalescing lesions with sporulation on the leaf surface, $80 \%$ to $90 \%$ of the foliage wilted, and 30\% to $70 \%$ of defoliation, and $4=$ near total defoliation, remaining leaves wilted and with large coalescing lesions. Trees with a 0 to 1 rating were considered to be resistant to alternaria late blight. Trees with a rating of 2 were considered tolerant, while trees with a rating of 3 to 4 were considered susceptible. Disease severities were recorded between late August and early September 1995 and 1997.

At KAC, a total of 2062 genotypes from 133 different crosses among 28 female and 35 male parents were scored for alternaria late blight infection in 1995 and 1997. At WEO, a total of 2246 genotypes at WEO from 108 crosses among 30 female and 35 male parents were scored. Twenty open pollinated (OP) families were included in the evaluations at both locations.

Field data analysis. The main effects of female parent $(\mathrm{F})$, male parent $(\mathrm{M})$, sex of the progeny (S; male, female, or unknown), location (L), block (B), and interactions between $\mathrm{S} \times \mathrm{F}, \mathrm{S} \times \mathrm{M}$, and $\mathrm{F} \times \mathrm{M}$ were tested using a random effects model with the SAS GLM procedure (SAS Institute Inc., 1985a) after arcsine square root transformation (arcsine $\sqrt{ } \mathrm{x}$ ) (Little and Hills, 1978). Analysis of variance (ANOVA) for progeny at KAC and WEO with Type III expected mean squares are presented in Table 1. Narrow sense heritabilities for alternaria late blight infection in pistachio progeny were estimated separately from half-sib analysis of $20 \mathrm{OP}$ families, 431 progeny at KAC, and 968 progeny at WEO (Becker, 1985) and are presented in Table 2. Data used for calculation of values in Table 2 are a subset from the total data set used for Table 1 . Narrow sense heritabilities were calculated as $\mathrm{h}^{2}=\left(4 \delta^{2} \mathrm{~F}\right) /\left(\delta^{2} \mathrm{~F}+\delta^{2} \mathrm{e}\right)$, where $\delta^{2} \mathrm{~F}$ was the variance among female parents and $\delta^{2} \mathrm{e}$ the component of variance due to error. The sES were calculated as described in Becker (1985). Data from KAC and WEO were analyzed separately in 1995 and 1997 because of large environmental difference from year to year and the possibility that different pathogen strains were present in 1995 and 1997.

GrEENHOUSE INOCULATION. Two greenhouse inoculations were conducted at KAC to test the feasibility of using controlled inoculation to minimize environmental variation and to determine the extent to which controlled and field-testing were correlated. OP progenies from 'Bronte', 'Iran Large', 'Kerman', 'Red Aleppo', and 'Trabonella' pistachio were selected based on the 1995 field evaluation data at KAC. Seedlings were grown in 3.8-L containers with a medium of composted 6 fir bark: 2 peat moss: 2 perlite (by

Table 3. Mean ratings \pm SD from five pollinated progenies of five pistachio cultivars after inoculation with Alternaria alternata isolates $25-\mathrm{A} 6-96$, 17-F12-94, and a water control. The seedlings were scored on a 0 to 4 scale: $0=$ healthy, $1=$ a few lower leaves with black necrotic areas, $2=$ lower leaves with necrotic lesions and upper leaves with necrotic areas, $3=$ lower leaves partially blightened and upper leaves with necrotic areas, and $4=$ majority of the leaves blightened and some small dark brown circular areas appearing on wilted leaves.

\begin{tabular}{|c|c|c|c|c|c|c|}
\hline \multirow[b]{2}{*}{ Female parent } & \multicolumn{3}{|c|}{1996 Inoculation } & \multicolumn{3}{|c|}{1997 Inoculation } \\
\hline & $25-\mathrm{A} 6-96$ & 17-F12-94 & Water & $25-A 6-96$ & 17-F12-94 & Water \\
\hline$\overline{\text { Bronte }}$ & $1.90 \mathrm{a}^{\mathrm{z}}(0.74)$ & $1.80 \mathrm{a}(0.63)$ & $1.90 \mathrm{ab}(0.32)$ & $1.00 \mathrm{a}^{\mathrm{y}}(1.04)$ & $1.43 \mathrm{a}^{\mathrm{x}}(0.98)$ & $1.00 \mathrm{a}^{\mathrm{w}}(1.10)$ \\
\hline Iran Large & $2.50 \mathrm{a}(0.97)$ & $2.00 \mathrm{ab}(1.33)$ & $1.40 \mathrm{a}(0.97)$ & $2.10 \mathrm{bc}(1.10)$ & $2.50 \mathrm{~b}(0.71)$ & $0.90 \mathrm{a}(0.88)$ \\
\hline Kerman & $3.70 \mathrm{~b}(0.84)$ & $3.40 \mathrm{~cd}(0.84)$ & 2.80 c (0.79) & $2.40 \mathrm{~cd}(0.97)$ & $2.90 \mathrm{bc}(0.74)$ & $1.60 \mathrm{a}(0.97)$ \\
\hline Red Aleppo & $3.71 b^{\mathrm{x}}(0.49)$ & $3.57 \mathrm{~d}^{\mathrm{x}}(0.53)$ & $2.33{b c^{\mathrm{w}}}^{(0.52)}$ & $2.80 \mathrm{~d}(0.79)$ & $3.20 \mathrm{c}(0.92)$ & $0.40 \mathrm{a}(0.70)$ \\
\hline Trabonella & $2.50 \mathrm{~b}(0.85)$ & $2.70 \mathrm{bc}(0.82)$ & $2.00 \mathrm{ab}(0.67)$ & $1.30 \mathrm{ab}(1.06)$ & $1.80 \mathrm{a}(0.79)$ & $0.78 \mathrm{a}^{\mathrm{v}}(0.83)$ \\
\hline
\end{tabular}

\footnotetext{
${ }^{\mathrm{z}}$ Mean separation within columns by Fisher's LSD at $P=0.05$.

y Mean of 8 seedlings.

${ }^{\mathrm{x}}$ Mean of 7 seedlings.

wMean of 6 seedlings.

${ }^{v}$ Mean of 9 seedlings.
} 
Table 4. Correlation coefficients among average greenhouse inoculation scores for OP families of five pistachio cultivars and with average field evaluation scores from the OP families of the five cultivars to alternaria late blight.

\begin{tabular}{|c|c|c|c|c|c|c|}
\hline \multirow[b]{3}{*}{ Inoculation } & \multicolumn{4}{|c|}{ Greenhouse inoculation } & & \\
\hline & \multirow{2}{*}{$\begin{array}{c}1996 \\
25-\mathrm{A} 6-96\end{array}$} & \multirow{2}{*}{$\begin{array}{c}1996 \\
17-F 12-94\end{array}$} & \multirow{2}{*}{$\begin{array}{c}1997 \\
25-A 6-96\end{array}$} & \multirow{2}{*}{$\begin{array}{c}1997 \\
17-F 12-94\end{array}$} & \multicolumn{2}{|c|}{ Field evaluation } \\
\hline & & & & & 1995 & 1997 \\
\hline 25-A6-96/1996 & --- & $0.95^{*}$ & $0.92^{*}$ & $0.92^{*}$ & 0.69 & -0.67 \\
\hline 17-F12-94/1996 & & --- & 0.78 & 0.78 & 0.50 & -0.60 \\
\hline 25-A6-96/1997 & & & --- & $1.00^{* *}$ & 0.64 & -0.59 \\
\hline 17-F12-94/1997 & & & & --- & 0.67 & -0.56 \\
\hline
\end{tabular}

Significant at $P=0.05$ or 0.01 , respectively.

volume) amended with $1.37 \mathrm{~kg} \cdot \mathrm{m}^{-3}$ oyster shell lime, and 10.76 $\mathrm{kg} \cdot \mathrm{m}^{-3} 14 \mathrm{~N}-4.2 \mathrm{P}-11.6 \mathrm{~K}$ slow-release fertilizer(Osmocote by Scott). Seedlings were grown in the greenhouse with natural lighting and the temperature ranged from 20 to $28^{\circ} \mathrm{C}$. Six to 8-month-old seedlings were inoculated on 26 Aug. 1996 and 29 Apr. 1997. Thirty OP seedlings from each cultivar were separated into three groups and randomized within each group on three separate greenhouse benches. Two isolates of A. alternata (25-A6-96 and 17-F12-94), and a water control were tested. Petri dish cultures of the Alternaria isolates were flooded with sterile water, and inoculum suspensions were adjusted to a concentration of $5 \times 10^{4}$ spores $/ \mathrm{mL}$. The seedlings were sprayed with the pathogen suspension to runoff, covered with plastic bags for $48 \mathrm{~h}$ and grown in the greenhouse for 6 weeks prior to scoring. The seedlings were scored on a 0 to 4 scale: $0=$ healthy, $1=\mathrm{a}$ few lower leaves with black necrotic areas; $2=$ lower leaves with necrotic lesions and upper leaves with necrotic areas; $3=$ lower leaves partially blightened and upper leaves with necrotic areas; 4 $=$ majority of the leaves blightened and some small dark brown circular areas appearing on wilted leaves. Results were analyzed by one way ANOVA (SAS Institute Inc., 1985a), after arcsine transformation. If a significant difference among the OP family means was identified at $P=0.05$, Fisher's least significant difference test (LSD) was then performed (Table 3 ). Correlation of family mean greenhouse inoculation scores with field evaluation scores for the five OP families in 1995 and 1997 (Table 4) were calculated using SAS PROC CORR procedure (SAS Institute Inc., 1985b).

\section{Results and Discussion}

Field evaluation of Pistachio Progeny at KaC and weo. ANOVA results for all progeny at KAC and WEO are presented in Table 1. Both female and male parents have effects on the alternaria late blight infection in progeny. Overall, the progeny seedlings had lower infection scores at WEO due to less favorable conditions for disease development such that only very susceptible seedlings had infection. At KAC only the most resistant genotypes did not show infection. Alternaria populations which differ in aggressiveness may be present at different locations. The pathogen population may also change from year to year. Individual pistachio genotypes may therefore respond differently from year to year. Differences in family response at different locations would also be expected (individual genotypes were not represented at multiple locations.) The action of multiple, different resistance genes in the hosts are probably being observed, accounting for differences in response patterns at KAC and WEO. The mean square values for alternaria late blight infection based on analysis of OP families at KAC and WEO are presented in Table 2. Female parents were a significant factor in determining the level of alternaria late blight infection.

Mean values (percentage) of resistant progeny (infection type 0 to 1 ) and tolerant progeny (infection type 2 ) by parent are presented in Fig. 1. Fifty-eight seedlings from 26 crosses were scored as resistant in both seasons at KAC. A high proportion of progeny of 'Red Aleppo' (from Syria), 'Bronte' (from Sicily), and 'Trabonella' (from Sicily) were resistant to alternaria late blight in 1995 (Fig. 1). Progeny of 'Sfax' (from Tunisia) and 'Aegina' (from Greece) had highest resistance in the 1997 evaluation. PI151361 provided the highest level resistance to progeny among all female parents while progeny from two male parents, no. 30 and PI104401 were even more resistant. These parents are excellent candidates for use in breeding A. alternata resistant cultivars. However, they will need to be combined with parents transmitting desirable nut characteristics to develop commercially acceptable cultivars. Among named female cultivars, 'Sfax' produced the highest proportion of resistant progeny in crosses with nine different male parents. The cross between 'Sfax' and male no. 30 had seven seedlings, all of which were highly resistant in 1995 and 1997 at KAC. Male parent no. 30 is an unnamed seed introduction of $P$. vera 'Kirmizi' from Gaziantep, Turkey. 'Kirmizi' is similar to 'Red Aleppo' from Syria and may have originated from the same region (S. Kafkas, personal communication). $P$. vera germplasm from different parts of the Mediterranean region may contain different resistance genes for alternaria late blight resistance. Germplasm from central Asia was generally susceptible to alternaria late blight.

HeRITABILITY ESTIMATES. Heritability estimates of alternaria late blight resistance are presented in Table 2. Half-sib analysis of 431 progeny from $20 \mathrm{OP}$ families at KAC gave narrow sense heritabilities of 0.48 and 0.11 for 1995 and 1997, respectively. Analysis of 968 progeny trees from $20 \mathrm{OP}$ families at WEO gave narrow sense heritabilities of 0.56 and 0.54 for 1995 and 1997 , respectively. Three of these estimates suggest that inheritance of pistachio progeny against alternaria late blight infection is moderately heritable and amenable to selection.

The smaller heritability estimate of narrow sense heritability at KAC in 1997 may reflect large seasonal environmental differences or a change in the genetic composition of the pathogen population. Environmental effects could result in large genotype $\times$ environment interactions that are accounted for in the denominator of the $\mathrm{h}^{2}$ estimate with a consequent reduction in measured heritability. It has been suggested that the interaction of two or three environmental factors with genotypes could reduce heritability values by one-half to one-third of their unadjusted values (Byrne et al., 1987). The narrow sense heritability estimates are similar to the heritability estimates obtained from other fruit-tree disease resistance studies. Heritability estimates of scab [Cladosporium caryigenum (Ell. Et Lang.) Gottwald] resistance in pecan [Caryaillinoinensis (Wangenh.) C. Koch] ranged from 0.476 to 0.540 (Thompson and Grauke, 1994), while estimates from 0.21 to 0.47 were found for eastern filbert blight [Anisogramma anomala (Peck) E. Mhller] resistance in European hazelnut (Corylus avellana L.) (Osterbauer et al., 1997). Heritability of fire blight [Ervinia amylovora (Burrill) 


\section{Resistant progeny}

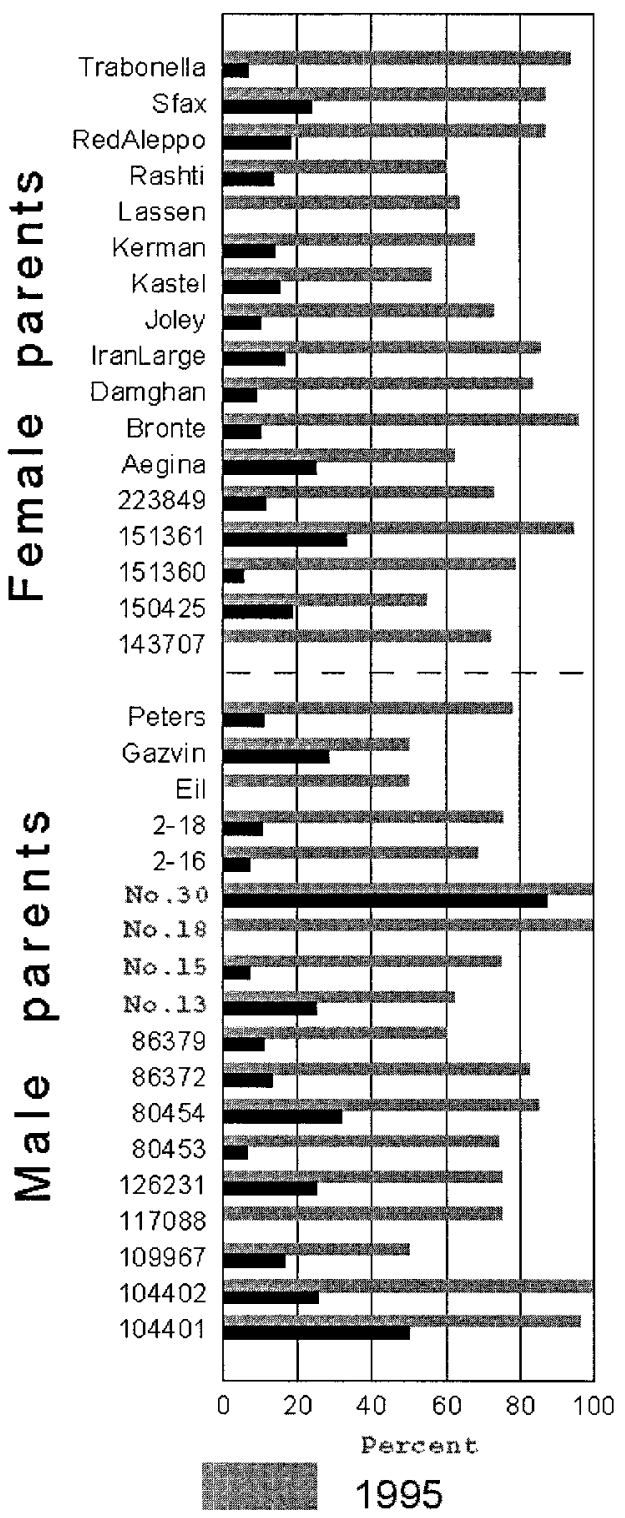

Tolerant progeny

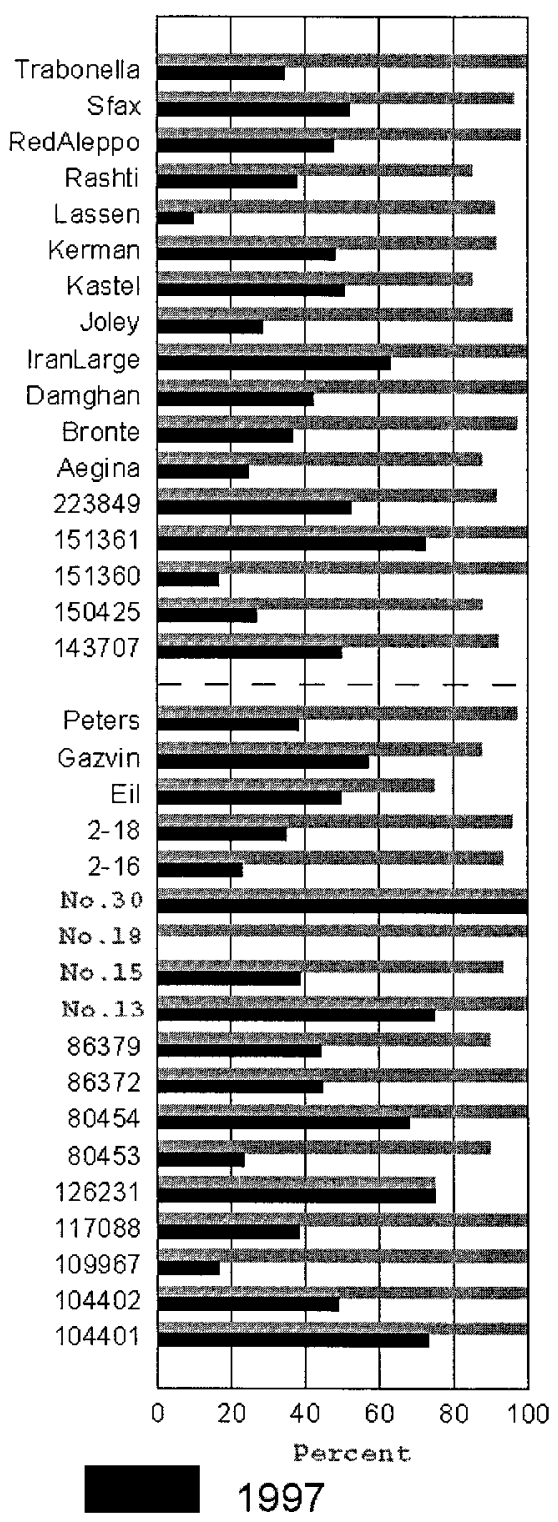

into eight different types (Adachi et al., 1993). The other 51 isolates had biotype mixtures as determined from rDNA polymorphisms. Isolates of A. alternata have been found to generatemixedrDNA patterns (Adachi and Tsuge, 1994). These isolates may be the result of either sexual or asexual recombination in the field. More than one A. alternata population with different pathogenicity could be present at KAC. A recent study of alternaria late blight populations on pistachio in California using rDNA RFLP polymorphism showed that populations at KAC and WEO are variable and generally clustered into three groups (Aradhya et al., 2000). A similar study based on morphology and RAPD analysis also identified three groups of Alternaria biotypes (Pryor and Michailides, 2000). They concluded that the three groups may represent different species. Different resistance alleles or loci of pistachio could interact with the pathogen in different years due to the changes in pathogen populations. Both additive and dominant genes could contribute to resistance to alternaria late blight in pistachio. Previous reports in the literature have described several models of gene action to explain resistance to Alternaria sp. In Japanese pears, resistance to black spot disease (Alternaria kikuchiana Tanka) was controlled by single recessive resistance genes (Kozaki, 1973). Resistance was identified in Japanese pear cultivars and in some wild species. In tomato (Lycopersicon esculentum Mill.), an incompletely dominant alternaria stem canker [Alternaria alternata $\mathrm{f}$. sp. Lycopersici (Fries)] resistance locus (Asclocus) was located on chromosome 3 (Witsenboer et al., 1989). Another allele of the Asc locus was found to be completely dominant in Lycopersiconpennellii Corr. (van der Biezen et al., 1995). The Asc locus also conferred insensitivity to host-specific toxins (AAL-toxins). Two isolates of A. alternata from pistachio also produced phytotoxins and

Fig. 1. Percentage of pistachio progeny resistant and tolerant to alternaria late blight at KAC in 1995 and 1997 grouped by female or male parents. Some of the crosses used in the data analysis are not illustrated. Percentages for susceptible progeny are not shown, but may be obtained as susceptible $=100 \%-($ resistant + tolerant).

Winslow et al.] resistance in pear (Pyrus L. sp.) was 0.52 (Bell et al., 1977). Narrow sense heritability of leaf blight [Alternaria dauci (Khhn) Groves \& Skolko] resistance in carrot (Daucus carota L.) ranged from 0.40 to 0.82 (Boiteux et al., 1993; Vieira et al., 1991). Resistance to leaf blight (Alternaria triticina Prasada \& Prabhu) in wheat (Triticum aestivum L.) was controlled by both additive and dominance genes (Sinha et al., 1991) as was resistance to alternaria leaf blight in carrot (Simon and Strandberg, 1998).

Alternaria alternata is a ubiquitous, saprophytic, imperfect haploid fungus. A nuclear ribosomal DNA variability study of Japanese pear (Pyrus serotina Rehd.) isolates of Alternaria alternata (Fries) Keissler showed that 271 of 322 isolates could be separated caused shoot wilting and leaf blight in bioassays done in the laboratory using culture filtrates from these isolates (Michailides and Morgan, 1991). Also, a high ratio of A. alternata isolates from pistachio produce crystals in culture, an indication of isolate ability to produce phytotoxin (Michailides, unpublished data). Both additive and dominant genes for resistance were shown to be functioning in carrot against leaf blight (Simon and Strandberg, 1998). Unfortunately, half-sib family analysis does not permit separate estimation of these effects. Theoretically, the half-sib analysis described by Becker (1985) should provide an estimate of additive effects. However, if dominance effects were present, they would be partitioned into both the numerator and denominator terms of the heritability estimate, resulting in an overestimate of narrow sense heritability.

Greenhouse inoculation. The OP progeny from 'Kerman', 'Iran Large', 'Red Aleppo', 'Bronte', and 'Trabonella' pistachio produced $27 \%, 48 \%, 68 \%, 80 \%$, and $90 \%$ resistant progeny, respectively, in the 1995 field evaluation at KAC. Average ratings 
of OP progenies of five pistachio cultivars in 1996 and 1997 greenhouse inoculations with two A. alternata late blight inocula and a water control are presented in Table 3. Significant differences among progeny families were observed in both seasons and with both isolates. Water controls in 1996 also showed significant differences that were not expected, while water controls in $1997 \mathrm{did}$ not show significant symptoms for any of the families. Progeny from 'Bronte' and 'Trabonella' showed the fewest symptoms while 'Red Aleppo' and 'Kerman' had the highest level of symptoms. Both 'Bronte' and 'Trabonella' are Mediterranean cultivars while 'Red Aleppo' and 'Kerman' are from drier central Asian regions.

Correlations between field evaluations and greenhouse evaluations for the OP progeny from the five female parents are presented in Table 4. Results from greenhouse inoculation of the two Alternaria strains were highly correlated as was correlation between both years. However, correlations between greenhouse and field results were only moderately positive in 1995 and were negative in 1997. This finding is very important since it suggests that controlled greenhouse screening of seedling progenies is not a satisfactory method for selection of potential resistant cultivars. Possible reasons for lack of agreement between greenhouse and field results could include 1) inability to duplicate the field environment in the greenhouse, 2) different resistance mechanisms are functioning in the field, or 3) different strains or species are present in the field, or 4) the leaf tissue in the field evaluation might be more mature and the leaf tissue in the greenhouse inoculation might be more juvenile.

Implication for breeding alternaria late blight resistant pistachio cultivars. Inheritance of resistance to alternaria late blight in pistachio is shown to be at a moderate level and therefore amenable to selection. From evaluation at the KAC plot, 58 individual seedlings have been identified with very high and consistent levels of resistance (infection type 0-1) in 1995 and 1997. Among these 58 seedlings, 38 have flowered ( 27 males and 11 females). These 38 seedlings were derived from several different parents including some from central Asia that had good yield and nut quality. These resistant seedlings will be useful as parents for breeding alternaria late blight resistant cultivars with superior horticultural performance. Seedlings of Mediterranean origin may have different genes for resistance than the central Asian materials. However, nut quality and yield of Mediterranean materials are lower (the nuts are smaller and have shells that stain easily). Breeding with these selections would require more crossing cycles to introduce resistance of the Mediterranean materials into central Asian germplasm with high nut quality and yield. The alternaria late blight resistance identified among the selected pistachio seedlings may represent several different resistance genes or alleles and/or combinations. Further testing with other isolates of A. alternata or testing in different environments and locations may be necessary to ensure durability of the resistance. Although consistent field evaluation will continue to be a problem, the overall prospects for developing commercially acceptable alternaria late blight resistant pistachio cultivars are very good.

\section{Literature Cited}

Adachi, Y. and T. Tsuge. 1994. Co-infection by different isolates of Alternaria alternata in single black spot lesions of Japanese pear leaves. Phytopathology 84:447-451.

Adachi, Y., H. Watanabe, K. Tanabe, N. Doke, S. Nishimura, and T. Tsuge. 1993. Nuclear ribosomal DNA as a probe for genetic variability in the Japanese pear pathotype of Alternaria alternata. Appl. Environ. Microbiol. 59:3197-3205.

Aradhya, M., D.E. Parfitt, and H. Chan. 2000. Variability in Alternaria alternata, p.118. In: California pistachio industry annual report. Crop year 1999-2000. Calif. Pistachio Commission, Fresno.
Becker, W.A. 1985. Manual of quantitative genetics. 4th ed. Academic Enterprises, Pullman, Wash.

Bell, R.L., J. Janick, R.H. Zimmerman, and T. van der Zwet. 1977. Estimation of heritability and combining ability for fire blight resistance in pear. J. Amer. Soc. Hort. Sci. 102:133-138.

Boiteux, L.S., P.T. Della Vecchia, and F.J.B. Reifschneider. 1993. Heritability estimate for resistance to Alternaria dauci in carrot. Plant Breeding 110:165-167.

Byrne, T., D. Drennan, and J. Harding. 1987. Genotype $\times$ environment interaction bias in heritability estimates for cut-flower yield of greenhouse gerberas. J. Amer. Soc. Hort. Sci. 112:724-727.

California Pistachio Commission. 1999. California pistachio industry annual report. Crop year 1998-1999. Calif. Pistachio Commission, Fresno.

Kozaki, I. 1973. Black spot disease resistance in Japanese pear I. Heredity of the disease resistance. Bul. Hort. Res. Sta. Japan Ser. A. 12:17-27.

Little, T.M. and F.J. Hills. 1978. Agricultural experimentation. Design and analysis. Wiley, New York.

Michailides, T.J. and D.P. Morgan. 1991. An integrated approach for control of late blight caused by Alternaria alternata and management of mycoflora of pistachio through manipulation of irrigation practices, p. 59-65. In: California pistachio industry annual report. Crop year 1990-1991. Calif. Pistachio Commission, Fresno.

Michailides, T.J., D.P. Morgan, and M.A. Doster. 1995. Foliar and fruit diseases, p. 148-160. In: L. Ferguson (ed.). Pistachio production. Center for Fruit and Nut Crop Res. and Info., Univ. California, Davis.

Michailides, T.J., D.P. Morgan, M.A. Doster, and R. Kölliker. 1994. Biology, epidemiology and control of Alternaria and Aspergillus blights of pistachio, and effects of these diseases on nut quality, p. 49-56. In: California pistachio industry annual report. Crop year 1993-1994. Calif. Pistachio Commission, Fresno.

Michailides, T.J., D.P. Morgan, and D. Felts. 1997. Control of Alternaria late blight of pistachio in California, p. 66-68. In: California pistachio industry annual report. Crop year 1996-1997. Calif. Pistachio Commission, Fresno.

Michailides, T.J., D.P. Morgan, and D.A. Goldhammer. 1996. Surface drip irrigation reduces Alternaria late blight of pistachio caused by Alternaria alternata (second-year report), p. 129-132. In: California pistachio industry annual report. Crop year 1995-1996. Calif. Pistachio Commission, Fresno.

Michailides, T.J., D.P. Morgan, and J. Wang. 1991. Control of Alternaria late blight of pistachio by manipulation of irrigation. Phytopathology 81:1163 (abstr.).

Osterbauer, N.K., K.B. Johnson, S.A. Mehlenbacher, and T.L. Sawyer. 1997. Analysis of resistance to eastern filbert blight in Corylus avellana. Plant Dis. 81:388-394

Parfitt, D.E., C.T. Chao, C. Kallsen, L. Ferguson, T. Michailides, S. Kafkas, and J. Maranto. 1998. Pistachio cultivar improvement: 1997, p. 134-142. In: California pistachio industry annual report. Crop year 1997-1998. Calif. Pistachio Commission, Fresno.

Pryor, B. and T.J. Michailides. 2000. Morphological and molecular diversity of Alternaria alternata causing alternaria blight of pistachio, p. 101. In: California pistachio industry annual report. Crop year 1999-2000. California Pistachio Commission, Fresno.

SAS Institute, Inc. 1985a. User's guide: Statistics. 5th ed. SAS Inst., Inc. Cary, N.C.

SAS Institute, Inc. 1985b. User's guide: Basics. 5th ed. SAS Inst., Inc. Cary, N.C. Simon, P.W. and J.O. Strandberg. 1998. Diallel analysis of resistance in carrot to Alternaria leaf blight. J. Amer. Soc. Hort. Sci. 123:412-415.

Sinha, B., R.M. Sigh, and U.P. Sigh. 1991. Genetics of leaf blight resistance in wheat. Theor. Appl. Genet. 82:399-404.

Thompson, T.E. and L.J. Grauke. 1994. Genetic resistance to scab disease in pecan. HortScience 29:1078-1080.

van der Biezen, E.A., T. Glagotskaya, B. Overduin, H.J.J. Nijkamp, and J. Hille. 1995. Inheritance and genetic mapping of resistance to Alternaria alternata $\mathrm{f}$. sp. lycopersici in Lycopersicon pennellii. Mol. Gen. Genet. 247:453-461.

Vieira, J.V., V.W.D. Casali, J.C. Milagres, A.A. Cardoso, and A.J. Regazzi. 1991. Heritability and genetic gain for resistance to leaf blight in carrot (Daucus carota $\mathrm{L}$.) populations evaluated at different times after sowing. Rev. Brazil Genet. 14:501-508.

Witsenboer, H.M.A., E.G. van de Griend, J.B. Tiersma, H.J.J. Nijkamp, and J. Hille. 1989. Tomato resistance to Alternaria stem canker: Localization in host genotypes and functional expression compared to non-host resistance. Theor. Appl. Genet. 78:457-462. 